\title{
SANKSI PRODUK YANG TIDAK BERLEBEL HALAL
}

\author{
Mospa Darma \\ Universitas Tjut Nyak Dhien \\ jhonluckylucky@yahoo.com
}

\begin{abstract}
In the world of business producers are vying to meet the needs of producers who are certain to be a benchmark in economic principles where suply depends on dimand, on the other hand demand depends on the needs of the community but all market demand is determined by the regulation applied by producers and governments.
\end{abstract}

Keywords: punishment, Products, Halal Labels

ABSTRAK : Dalam dunia bisnis produsen berlomba-lomba untuk memenuhi kebutuhan para produsen yang sudah pasti menjadi tolok ukur didalam prinsip ekonomi dimana suply tergantung pada dimand, dari sisi lain permintaan tergantung dari kebutuhan komunitas masyarakat namun segala permintaan pasar ditentukan akan regulasi yang diterapkan produsen dan pemerintah.

Kata Kunci : Sanksi, Produk, Label Halal

\section{Pendahuluan}

Periode akhir-akhir ini dimana populasi dibelahan dunia memberikan gambaran dimana pertumbuhan populasi Muslim semakin meningkat seiring berjalannya waktu. Populasi Muslim mengambil 30 persen dari total populasi dan diperkirakan pada tahun 2025 populasi Muslim akan meningkat hingga 35 persen. Oleh karena itu, tidak heran apabila konsumsi produk halal semakin meningkat dan begitu pula permintaan akan produk halal. Halal dan industri terkait telah menjadi pasar yang penting dan bisnis yang menguntungkan, sama halnya dengan potensi investasinya yang besar (Yusoff dan Adzharuddin, 2017: 1). Bahkan menurut Hussein Elasrag (2016: 7) pada tahun 2050 jumlah populasi kaum muslim diprediksi akan mencapai 2.6 Milyar.

Produk secara otomatis akan tunduk terhadap pasar yang telah tunduk pada peraturan dan intervensi pemerintah ke berbagai tingkatan baik dalam sosialis, masyarakat totaliter dan modal masyarakat liberal. Islam, sejak awal, telah hak individu yang diakui di pasar bebas dan perdagangan bebas, tetapi dalam prinsip dan aturan yang ditetapkan oleh Syariah Di antara aturan syariah ini adalah berikut: pertama, perdagangan hanya dapat dilakukan dengan barang yang halal, diizinkan oleh syari'at, atas dasar pilihan bebas dan persetujuan bersama antara pembeli dan penjual. Kedua, transaksi tunai Ini melibatkan pengiriman barang dagangan yang sebenarnya dan pembayaran penuh harga secara simultan.

Setiap umat Islam wajib hukumnya dalam mengkonsumsi makanan halal. Syariat Islam telah mengatur cara pemenuhan kebutuhan pangan manusia seperti yang tertera dalam $\mathrm{Al}$ Qur' an surat Al Maidah ayat 88. Dalam Al Qur' an disebutkan bahwa makanan yang halal adalah semua jenis makanan, kecuali yang secara khusus disebutkan sebagai haram yang dilarang atau melanggar hukum Islam sep Label halal menjadi salah satu kriteria yang sangat penting yang dapat digunakan untuk membedakan sehingga juga bertujuan untuk membantu konsumen terutama konsumen muslim untuk mengevaluasi produk dan meyakinkan mereka akan kualitas produk tersebut. Seperti yang kita ketahui bahwa jumlah penduduk muslim di Indonesia sangat besar. Banyaknya penduduk muslim di Indonesia tentu membawa pengaruh yang besar bagi budaya yang berkembang di Indonesia seperti yang dijelaskan dalam Al Qur' an surat Al Maidah ayat 3.

Label halal menjadi salah satu kriteria yang sangat penting yang dapat digunakan untuk membedakan sehingga juga bertujuan untuk membantu konsumen terutama konsumen muslim untuk mengevaluasi produk dan meyakinkan mereka akan kualitas produk tersebut. Seperti yang kita ketahui bahwa jumlah penduduk muslim di Indonesia sangat 
besar. Banyaknya penduduk muslim di Indonesia tentu membawa pengaruh yang besar bagi budaya yang berkembang di Indonesia.

Dalam kenyataannya produk yang dikonsumsi kedalam tubuh bisa menjadikan hingga ke sel biologis keturunan. Maka bicara tentang makanan, halal-haram, berarti bicara tetang keturunan dan generasi pelanjut yang akan menentukan masa depan peradaban umat manusia dengan karakteristik halal-haram tersebut Produk-produk olahan, baik makanan, minu-man, obat-obatan, maupun kosmetika, kiranya dapat dikategorikan ke dalam kelompok musy-tabihat (syubahat), apalagi jika produk tersebut berasal dari negeri yang penduduknya mayoritas nonmuslim, sekalipun bahan bakunya berupa barang suci dan halal.

Halal (Arab: حلالhalāl; 'diperbolehkan') adalah segala sesuatu objek atau kegiatan yang diizinkan untuk digunakan atau dilaksanakan secara agama Islam dan halal ditinjau dari jenisnya dan caranya. Persamaan halal adalah thayyib yang berarti 'baik'. Sehingga makanan dan minuman tidak hanya halal, tetapi harus thayyib; apakah layak dikonsumsi atau tidak, atau bermanfaatkah bagi kesehatan. Lawan halal adalah haram. Halal sebagai salah satu dari lima hukum, yaitu: fardhu (wajib), mustahab (disarankan), halal (diperbolehkan), makruh (dibenci), haram (dilarang). Ketika berbicara tentang manusia, Al-Qur'an menggunakan tiga istilah pokok. Pertama, menggunakan kata yang terdiri atas huruf alif, nun, dan sin, seperti kata insan, ins, nas, dan unas. Kedua, menggunakan kata basyar. Ketiga, menggunakan kata Bani Adam dan zurriyat Adam. Demikian halnya, segala sesuatu yang halal itu baik dan bagus, tetapi sebagiannya ada yang lebih baik dan bagus dari yang lainnya, lebih bersih, lebih suci dan lebih murni dari yang lainnya. Makanan memiliki dampak yang besar dalam kehidupan seseorang, baik itu makanan halal maupun yang haram.

Monzer Kahf memberikan trobosan yang berasumsi sebagai berikut yakni: Islam dilkaksanakan oleh masyarakat, zakat hukumnya wajib, tidak ada riba dalam perekonomian, mudharabah wujud dalam perekonomian, pelaku ekonomi mempunyai perilaku memaksimalkan. Siddiqi menyatakan, bahwa tujuan aktifitas ekonomi yang sempurna menurut Islam antara lain: (a) Memenuhi kebutuhan hidup seseorang secara sederhana.(b) Memenuhi kebutuhan keluarga (c) Memenuhi kebutuhan jangka panjang.(4) Memenuhi kebutuhan keluarga yang ditinggalkan. (5) Memberikan bantuan sosial dan sumbangan menurut jalan Allah ${ }^{1}$

Menurut Ibn Khaldun, ketika mazhab para imam fiqh menjadi ilmu khusus bagi pengikutnya dan tidak ada jalan melakukan ijtihad, maka ulama melakukan tandzir atau penyamaan untuk dihubungkan serta memilahnya ketika terjadi ketidakjelasan setelah menyederhanakan setiap dasar-dasar tertentu dari mazhab mereka. Dengan cara tandzir dan isytibāb (dipilah) fiqh dikembangkan dan selanjut-nya ulama meletakkan cara-cara baru dalam ilmu fiqh yang disebut al-Qawāid al-Dhawābith atau alFurūq dan mazhab Hanafi dikenal sebagai mazhab yang pertama memperkenalkan ilmu ini.

Perlindungan konsumen Muslim menjadi penting di Indonesia, karena sebagian besar konsumen Indonesia adalah Muslim. Karena itu, konsumen Muslim harus mendapatkan perlindungan barang dan jasa baik makanan atau obat-obatan sesuai dengan syariah. Di sisi Perlindungan produk halal adalah melalui LPPOM MUI atau Lembaga Pengkajian Pangan Obat-Obatan dan Kosmetika Majelis Ulama Indonesia (LPPOM MUI) berdiri pada 6 Januari 1989. Lembaga ini berfungsi melindungi konsumen Muslim dalam penggunaan produk-produk makanan, obatobatan, dan kosmetik. Sedangkan Badan Halal Dunia (WHC) World Halal Council (WHC) berdiri pada 1999 di Jakarta yang diinisiasi oleh sejumlah negara, termasuk Indonesia. Badan ini berfungsi sebagai federasi badan sertifikasi halal di seluruh dunia setelah mendapat- kan penerimaan internasional dan global untuk sertifikasi dan akreditasi proses halal mereka.Lukman Hakim, Direktur Eksekutif Lembaga Pengkajian Pangan, Obat-obatan dan Kosmetika Majelis Ulama Indonesia (LPPOMMUI) dalam Zuhri mengemukakan bahwa dari jumlah produk makanan dan minuman yang beredar di seluruh Indonesia, hanya ribuan saja yang mengantongi sertifikat halal dari LPPOMMUI yaitu baru sekitar 20 persen dari keseluruhan yang sudah disertifikasi halal oleh $\mathrm{MUI}^{2}$, lain pemerintah harus melindungi konsumen Muslim di Indonesia.

Label halal adalah jaminan yang diberikan oleh suatu lembaga yang berwenang seperti 
Lembaga Pengkajian Pangan Obat-Obatan dan Kosmetika Majelis Ulama Indonesia (LP POM MUI) untuk memastikan bahwa produk tersebut sudah lolos pengujian kehalalan sesuai syariat Islam ${ }^{3}$ Jaminan penyelenggaraan produk halal bertujuan memberikan kenyamanan, keamanan, keselamatan, dan kepastian ketersediaan produk halal bagi masyarakat dalam mengkonsumsi dan menggunakan produk halal, serta meningkatkan nilai tambah bagi pelaku usaha untuk memproduksi dan menjual produk halal.

Menurut Ajzen dan Fishbein pada umumnya seseorang sangat rasional dalam memanfaatkan informasi yang tersedia serta mempertimbangkan implikasi dari tindakan tersebut sebelum memutuskan untuk terlibat atau tidak dalam perilaku tersebut, dengan kata lain disini informasi berperan penting ${ }^{4}$.

Syarat kehalalan suatu produk diantaranya:

a. Tidak mengandung bahan yang berasal dari babi dan anjing.

b. Tidak mengandung bahan-bahan yang diharamkan seperti bahan-bahan yang berasal dari organ manusia,darah, kotorankotoran, dan lain sebagainya.

c. Semua bahan yang berasal dari hewan halal yang disembelih menurut tata cara syariat Islam.

d. Semua tempat penyimpanan, tempat penjualan, pengolahan, tempat pengelolaan dan transportasinya tidak boleh digunakan untuk babi. Jika pernah digunakan untuk babi atau barang yang tidak halal lainnya terlebih dahulu harus dibersihkan dengan tata cara yang diatur menurut syariat Islam.

e. Semua makanan dan minuman yang tidak mengandung khamar.

f. Produk yang dikonsumsi tidak mengandung bahan yang merusak, berbahaya, membinasakan pengguna.

Tahapan berikut dapat dipakaiuntuk menyusun Haram Analysis Critical Control Point (HrACCP).

1. Tentukan dan akses seluruh bahan yang haram dan najis

2. Tentukan titik-titik kendali kontrol.

3. Buat prosedur pemantauan.

4. Adakan tindakan untuk mengkoreksi.

5. Adakan Sistem pencatatan

6. Buat prosedur verifikasiPenentuan.

\section{Hukum Nasional}

Resolusi Majelis Umum PBB N.A/ RES/39/248 Tahun 1985 tentang Guidelines for Consumer Protectiondan Dasar hukum yang terkait sertifikasi:

1. Undang-Undang Nomor7 Tahun 1996tentang Pangan;

2. UU No 8 tahun 1999 Perlindungan Konsumen;

3. Keputusan Menteri Kesehatan Republik Indonesia924/Menkes/SK/VIII/ 1996tentang perubahan atas Keputusan Menteri Kesehatan RI

No.82/Menkes/SK/I/1996tentang

Pecantuman Tulisan Halalpada Label Makanan;

4. Undang-Undang Republik Indonesianomor 33tahun 2014tentangjaminan Produk Halal

Sesuai Peraturan Menteri Perdagangan Nomor 31 tahun 2011 Tentang Barang Dalam Keadaan Terbungkus (BDKT), label pangan keterangan yang berupa tulisan, gambar, dan kombinasi yang memberikan informasi sesuai dengan peraturan perundangan yang ditempelkan pada bagian kemasannya.

Undang Nomor 33 Tahun 2014 tentang Jaminan produk halal, pada Pasal 4 disebutkan: Produk yang masuk, beredar, dan diperdagangkan di wilayah Indonesia wajib bersertifikat halal.Pasal 5 (1) Pemerintah bertanggung jawab dalam menyelenggarakan JPH.

Aspek yang menjaditinjauan dalam labelisasi halal, yaitu:

a. Proses Pembuatan Proses pembuatan atau proses produksi perusahaan yang sudah menggunakan label halal hendaknya harus tetap menjaga hal-hal sebagai berikut:

1) Binatang yang hendak dibersihkan,binatang yang sudah mati setelah disembelih

2) Bahan campuran yang digunakan dalam proses produksi tidak terbuat dari barang-barang atau bahan yang haram dan turunannya.

3) Air yang digunakan untuk membersihkan bahan hendaklah air mutlak atau bersih dan mengalir.

4) Dalam proses produksi tidak tercampur atau berdekatan dengan barang atau najis atau haram.

b. Bahan Baku Utama Bahan baku produk adalah bahan utama yang digunakan dalam kegiatan proses produksi,baik berupa bahan baku,bahan setengah jadi maupun bahan 
jadi. Sedangkan bahan tambahan produk adalah bahan yang tidak digunakan sebagai bahan utama yang ditambahkan dalam proses teknologi produksi.

c. Bahan Pembantu Bahan pembantu atau bahan penolongadalah bahan yang tidak termasuk dalam kategori bahan baku ataupun bahan tambahan yang berfungsi untuk membantu mempercepat atau memperlambat proses produksi termasuk proses rekayasa.Rekayasa genetika adalah suatu proses yang melibatkan pemindahan gen pembawa sifat dari suatu jenis hayati ke jenis hayati lain yang berbeda atau sama untuk mendapatkan jenis batu yang mampu menghasilkan produk pangan yang lebih unggul ${ }^{5}$.

Dalam PP No. 69 tahun 1999 pasal 1 pangan halal adalah pangan yang tidak mengandung unsur atau bahan yang haram atau dilarang untuk dikonsumsi umat Islam baik menyangkut bahan baku pangan bahan bantu dan bahan penolong lainnyatermasuk bahan pangan yang diolah melalui proses rekayasa genetika dan irradiasi pangan dan pengelolaannya dilakukan sesuai dengan ketentuan hukum agama Islam.Makanan yang halal adalah semua jenis makanan yang tidak mengandung unsur atau bahan yang terlarang haram dan atau diolah diproses menurut agama Islam.(Keputusan bersama Menkes dan MenagNo. /me.kes VIII/ 1985 dan No.68 tahun 1985 pasal 18.Perkembangan peraturan perundang undangan terkait pangan halal di Indonesiaadalah sebagai berikut:

Peraturan Menteri Kesehatan RINo. 280 /Menkes/ Per/XI/1976 tentang KetentuanPeredaran dan Penandaan pada Makanan yan' mengandung bahan berasal dari babi.

Pasal 2:

1) Pada wadah atau bungkus makanan yang diproduksi di dalam negeri maupun yang berasal dari impor yang mengandung bahan yang berasaldari babi harus dicantumkan tanda peringatan.

2) Tanda peringatan tersebut yang dimaksud pada ayat 518 harus berupa gambar babi dan tulisan yang berbunyi :Mengandung Babi danharus ditulis dengan hurufbesar berwarna merah dengan ukuran sekurang kurangnya ,Universe Medium Corp 12 di dalam garis kotak persegi yang berwarna merah.

3) Permenkes RI No. 76/Menkes/Per/III/78 tentang label dan Periklanan Makanan pasal2 menyatakan bahwa Kalimat kata-kata tanda lambang logo gambar dan sebagainya yang terdapat pada label atau iklan harussesuai dengan asal,sifat, komposisi, mutu dan kegunaan makanan.

4) Surat Keputusan bersama antara Menteri Agama dan Menteri Kesehatan No.427/Menkes/SKB/8/1985 dan No. 68/1985 tentang Pencantuman tulisan halal pada label Makanan.

Pasal 1 tulisan halal adalah tulisan yang dicantumkan padalabel/penandaan yang memberikan jaminan tentang halalnya makanan tersebut bagi pemeluk agama Islam Pasal 2 Produsen yang mencantumkan tulisan halal pada label atau penandaan makanan produknya bertangung jawab terhadap halalnya makanan tersebut bagi pemeluk agama Islam.

Pasal 4:

1) Pengawasan preventif terhadap ketentuan pasal 2 Keputusan bersama inidilakukan oleh Tim Penilaian Pendaftaran Makanan DepartemenKesehatan RI cq.Direktorat Jenderal Pengawasan obat dan Makanan.

2) Dalam tim penilaian pendaftaran makanan sebaaimana dimaksud padaayat (1) pasal ini, diikutsertakan unsur Departemen Agama RI.

3) Pengawasan di lapangan terhadap pelaksanaan ketentuan pasal 2Keputusan bersama ini dilakukan oleh aparat Departemen Kesehatan RI.

4) UU No. 23 tahun 1992 tentang Kesehatan, pasal 214 ayat 2 penjelasan butir (d)Ketentuan lainnya misalnya pencantuman kata atau tanda halal yang menjamin bahwamakanan dan minuman yang dimaksud diproduksi dan diprosessesuai dengan persyaratan makanan.

5) UU No. 7 tahun 1996 tentang Pangan, pasal (34)ayat (1) Setiap orang yang menyatakan dalam label atau iklan bahwa pangan yang diperdagangkan 
adalah sesuai dengan persyaratan agama atau kepercayaan tertentu bertanggung jawab atas kebenaran peryataan berdasarkan persyaratan agama atau kepercayaan tersebut.

Penjelasan Pasal 34 ayat (1)dalam ketentuan ini benar tidaknya suatu pernyataan halal dalam label atau iklan pangan tidak hanya dapat dari segi bahan baku pangan,bahan tambahan pangan atau bahan bantu lainnya yang digunakan dalam memproduksi pangan tetapi mencakup pula proses pembuatannya.

Pasal 56 uu No.33/2014;Pelaku Usaha yang tidak menjaga kehalalan Produk yang telah memperoleh Sertifikat Halal sebagaimana dimaksud dalam Pasal 25 huruf $\mathrm{b}$ dipidana dengan pidana penjara paling lama 5 (lima) tahun atau pidana denda paling banyak Rp2.000.000.000,00 (dua miliar rupiah).

Keputusan Menkes RI No. 82/Menkes/SK/I/1996 tentang Pencantuman tulisan halal pada label Makanan dan perumahannya berupa Keputusan Menteri Kesehatan RINo.924/Menkes/SK/VII/1996 beserta peraturan pelaksanaannya berupa Keputusan Dirjen POM No. IIK. 00.06.3.00568 tentang tata cara Pencantuman tulisan halal pada label Makanan yang antara lain menjelaskan:

1. Persetujuan pencantuman tulisan halal pada label makanan diberikan oleh Dirjen POM.

2. Produk makanan harus terdaftar pada Departemen Kesehatan RI.

3. Persetujuan Pencantuman label halal diberikan setelah dilakukan pemeriksaan dan penilaian oleh Tim yang terdiri dari Departemen Kesehatan, Departemen Agama dan MUI.

4. Hasil Penilaian Tim Penilai disampaikan kepada Komisifatwa MUI untuk dikeluarkan fatwanya dan akhirnya diberikan Sertifikat halal.

5. Persetujuan Pencantuman halal diberikan oleh Dirjen POM berdasarkan sertifikat halal yangberdasarkan MUI.
6. Persetujuan berlaku selama 2 tahun sesuai dengan sertifikatnya.

UU No.8 tahun 1999 tentang Perlindungan Konsumen yaitu :

Pasal 7 butir (b):

Pelaku usaha berkewajiban memberikan informasi yang benar jelas dan jujur mengenai kondisi dan jaminan barang danatau jasa.

Pasal 8 ayat 1 butir (b):

Pelaku usaha dilarang memproduksi dan /atau memperdagangkan barang dan /atau jasa yang tidak mengikuti ketentuan merproduksi secara halal.Sebagaimana pernyataan halal yang dicantumkan dalam label.

PP No. 69 tahun 1999 tentanglabel dan iklan Pangan

Pasal 10 Setiap orang yang memproduksi atau memasukkan pangan yang dikemas kedalam wilayah Indonesia untuk diperdagangkan dan menyatakan bahwa pangan tersebut halal bagi umat manusiabertanggung jawab atas kebenaran pernyataan tersebut dan wajib mencantumkan keterangan atau tulisan halal pada labeliiPernyataan halalsebagaimana dimaksud pada ayat (1) merupakan bagian yang tidak terpisahkan dari label Pasal 11:

1) untuk mendukung kebenaran pernyataan halalsebagaimana dimaksuddalam pasal 10 ayat (1)setiap orang yang memproduksi ataumemasukkan pangan yang dikemas ke dalam wilayah Indonesia untuk diperdagangkan wajib memeriksakan terlebih dahulu pangan tersebut pada lembaga pemeriksa yang telah diakreditasi sesuai dengan ketentuan peraturan perundangundangan yang berlaku.

2) Pemeriksaan sebagaimana dimaksud pada ayat (1) dilaksanakan berdasarkan Pedoman dan tata cara yang ditetapkan oleh Menteri Agamadengan memperhatikan pertimbangan dan saran lembaga keagamaan yang memiliki kompetensi dibidang tersebut.

Pasal 59: 
Pengawasan terhadap pelaksanaan ketentuan tentang label dan iklandilaksanakan oleh Menteri Kesehatan.

Pasal 60:

1) Dalam melaksanakan ketentuan sebagaimana dimaksud dalam pasal 59Menteri Kesehatan menunjuk pejabat untuk diserahi tugas pemeriksaan.

2) PejabatPemeriksa sebagaimana dimaksud dalam ayat (1) dipilih danditunjuk oleh Menteri Kesehatan berdasarkan keahlian tertentu yan'dimiliki.

3) PejabatPemeriksasebagaimana dimaksud dalam ayat (1) diangkat dandiberhentikan oleh Menteri Kesehatan.

Penjelasan PP No. 69 tahun 1999 pasal 11 ayat 1 menyatakan Pencantuman tulisanhalal pada dasarnya bersifatsukarela. Menurut Sampurno (2001)sanksi terhadap pelanggaran ketentuan pancantuman label dapat dikenakan :

Pidana penjara paling lama 3 (tiga) tahun dan atau denda paling banyak Rp.360.000.000 untuk pelanggaran terhadap UU No. 7 tahun 1999 pasal 34 ayat(1).

Tindak pidana penjara sampai 5 (lima) tahun atau denda sampai dua milyar rupiah untuk pelanggaran terhadap UU No.8 tahun 1999 pasal 8 ayat (1)butir h.

Tindakan administratif terhadap pelanggaran PP No. 69 tahun 1999 yang meliputi:

1) Peringatan secara tertulis.

2) Larangan untuk mengedarkan untuk sementara waktu dan atau perintahuntuk menarik produk pangan dari peredaran.

$\underline{\text { Al-Quran }}$

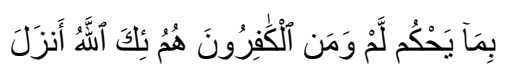

"Barangsiapa yang tidak memutuskan menurut apa yang diturunkan Allah, maka mereka itu adalah orang-orang yang kafir" [AlMaidah/5 : 44]

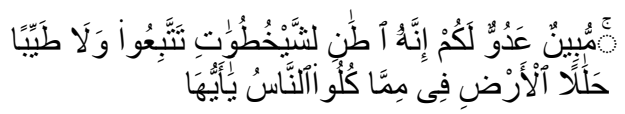

Hai sekalian Manusia, makanlah dari apa yang terdapat di bumi, yang halal dan yang thoyyib. Dan janganlah kamu menuruti jejak setan (yang suka melanggar atau melampaui batas). Sesungguhnya setan itu adalah musuh kamu yang nyata. (QS /2:168).

Hadis

Ibnu Abbas berkata bahwa Sa'ad bin Abi Waqash berkata kepada Nabi Muhammad SAW, "Ya Rasulullah, doakanlah aku agar menjadi orang yang dikabulkan doa-doanya oleh Allah". Apa jawaban Rasulullah, "Wahai Sa'ad perbaikilah makananmu (makanlah makanan yang halal) niscaya engkau akan menjadi orang yang selalu dikabulkan doanya. Dan demi jiwaku yang ada di tangan-Nya sungguh jika ada seseorang yang memasukkan makanan haram ke dalam perutnya, maka tidak akan diterima amalnya selama 40 hari dan seorang hamba yang dagingnya tumbuh dari hasil menipu dan riba, maka neraka lebih layak untuknya" (HR. At-Thabrani).

Hal ini dikuatkan dengan sabda Rasulullah SAW,

"Perkara yang halal itu jelas dan yang haram itu jelas, sedangkan diantara keduanya terdapat perkara-perkara yang tersamar (meragukan) dan banyak orang tidak mengetahuinya. Maka siapa yang menghindari perkara-perkara yang meragukan, iapun telah membersihkan kehormatan dan agamanya. Dan siapa yang terjerumus dalam perkara-perkara yang meragukan, iapun bisa terjerumus dalam perkara yang haram. Seperti penggembala yang menggembala di sekitar tempat terlarang dan nyaris terjerumus di dalamnya." (HR. Bukhari dan Muslim).

\section{Kesimpulan}

Bahwa produk yang beredar dipasaran haruslah mencantumkan lebel halal ataupun lebel tidak halal sehingga masyarakat Muslim dapat dengan yakin untuk mengkonsumsi produk yang beredr di pasaran dan pemerintahpun hendaknya lebih tegas dan agresif dalam penanganan produk yang beredar di pasaran tanpa lebel halal atau lebel non halal secarmasa berlakunya yang masih aktif.

\section{DAFTAR PUSTAKA \\ Jurnal}

Aat Hidayat, Jurnal, Psikologi Dan Kepribadian Manusia:Perspektif Al-Qur'an Dan Pendidikan Islam, STAIN Kudus, Jawa Tengah, Indonesiaaathiedayat@gmail.com dalam M. Quraish Shihab, Wawasan AlQur'an: Tafsir Tematik atas Pelbagai Persalan Umat (Bandung: Mizan, 2007). 
Abdel Rahman Yousri, Pasar Di Dalam Islam Sistem Ekonomi, Profesor Ekonomi Islam, Universitas Alexandria, Mesir,tt .

Adinugraha, Hendri Hermawan *, Wikan Isthika, Mila Sartika, Persepsi Label Halal Bagi Remaja Sebagai Indikator Dalam Keputusan Pembelian Produk: As a Qualitative Research Universitas Dian Nuswantoro Semarang, Perisai, Vol 1 (3), October 2017, 180-195 ISSN 2503-3077 (Online) Journal Homepage: http://ojs.umsida.ac.id/index.php/perisai DOI Link:http://doi.org/10.21070/perisai.1365 Article DOI: 10.21070/perisai.1365.

Alvi Jauharotus Syukriya, Hayyun Durrotul Faridah, Jurnal, Kajian Ilmiah Dan Teknologi Sebab Larangan Suatu Makanan Dalam Syariat Islam, Departemen Biologi, Fakultas Sains dan Teknologi, Universitas Airlangga Pusat Riset dan Pengembangan Produk Halal, Universitas Airlangga Kampus C UNAIR, J1. Mulyorejo, Surabaya 60115 *Email: hayyunfarida@gmail.com.

Anggit Listyoningrum, Albari, ANALISIS MINAT BELI KONSUMEN MUSLIM TERHADAP PRODUK YANG TIDAK DIPERPANJANG SERTIFIKAT

HALALNYA, Jurnal Ekonomi \& Keuangan Islam Volume 2 No. 1, Januari 2012: 40-51 Fakultas Ekonomi, Universitas Islam Indonesia.

Eka Dewi Setia Tarigan, Pengaruh Gaya Hidup, Label Halal Dan Harga Terhadapkeputusan Pembelian Kosmetik Wardah Pada Mahasiswa Programstudi Manajemen Fakultas Ekonomi Universitas Medan Area Medan, Jurnal,Dosen Fakultas Ekonomi Universitas Medan Area, Jurnal Konsep Bisnis dan Manajemen 47ISSN :2407-2648E-ISSN :2407-263XVol. 3 No. 1, November 2016.

Engel, Perilaku Konsumen Jilid 1. Edisi ke Enam, Terjemahan oleh Budiyanto, (Jakarta: Binarupa Aksara, 1994).

Ika Yunia Fauzia dan Abdul Kadir Riyadi, Prinsip Dasar Ekonomi Islam Perspektif Maqashid Al-Syari"ah, Jakarta: Kencana Prenada media Group, 2014.

Muchamad Fauzi, Jurnal, Fatwa dan Problematika Pentapan Hukum Halal Di Indonesia, Fakultas Ekonomi dan Bisnis Islam Universitas Islam Negeri Walisongo, Indonesia *Email korenpondensi: mfuz73@gmail.com.
Rivan Sutrisno, SE., MA., Perilaku Konsumen Muslim: Persepsi Religiusitas Dan Persepsi Atribut Produk Terhadap Loyalitas Produk Makanan Dan Minuman Berlabel Halal Di Kalangan Mahasiswa Muslim Di Bandung, Sigma-Mu Vol.5 No.2 - September 2013 (Staf Pengajar Jurusan Administrasi Niaga Politeknik Negeri Bandung).

Shilachul Alfinul Alim M Kholid Mawardi Aniesa Samira Bafadhal, Pengaruh Persepsi Label Halal Dan Kualitas Produk Terhadap Keputusan Pembelian Produk Fesyen Muslim ( Survei pada Pelanggan Produk Zoya Muslim di Kota Malang ) Fakultas Ilmu Administrasi Universitas Brawijaya Malang, Jurnal Administrasi Bisnis (JAB)|Vol. 62 No. 1 September 2018|.

Sulhan Abu Fitra, "Makanan Menentukan Kualitas Generasi dan Peradaban", dalam Jurnal Halal No. 113/Mei-Juni Th.XVIII 2015, (Mei-Juni 2015).

Sucipto,Jurnal, Halal Dan Haram Menurut AlGhazali Dalam Kitab Mau'idhotul Mukminin, dalam Al-Qasimi, Mau'idhah ....,.

Zulham, Hukum Perlindungan Konsumen,Kencana Pranada Media Group, Jakarta, , 2013.

\section{Internet}

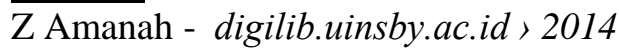

